\title{
LA PREECLAMPSIA, PROBLEMA DE SALUD PÚBLICA
}

\author{
Enrique Guevara Ríos ${ }^{1 a}$
}

La preclampsia es un desorden del embarazo asociado con el inicio de hipertensión después de las 20 semanas, con o sin proteinuria, y con la presencia o no, de una gran variedad de síntomas como dolor en cuadrante superior derecho del abdomen, cefalea ${ }^{1}$. Es una enfermedad de carácter irreversible que afecta múltiples órganos y, debido a que lesiona a la madre y al feto, es responsable de una proporción considerable de muertes maternas y perinatales.

Según la Organización Mundial de la Salud, la preeclampsia es la segunda causa de muerte en el mundo con un 14\% 2; y en el Perú en el I semestre del 2018 fue la primera causa de muerte materna con un $28,7 \%{ }^{3}$.

En el Instituto Nacional Materno Perinatal entre el 2007 y el 2018 se produjeron 97 casos de muerte materna, y la preeclampsia fue la primera causa con un 44,3\% ${ }^{4}$. Asimismo entre el 2012 y el 2018 se atendieron en el instituto un total de 1870 casos de morbilidad materna extrema, siendo la principal causa los transtornos hipertensivos del embarazo con el 56,6\% (164 casos) entre preeclampsia con criterios de severidad, síndrome HELLP y eclampsia ${ }^{4}$.

Por lo tanto la preeclampsia siendo un problema de una gran magnitud y una gran repercusión social, debe ser considerada como un problema de salud pública. Por esta razón, entre el 2016 y el 2017, el Instituto Nacional Materno Perinatal, conjuntamente con el Instituto Nacional de Salud, Hospital San Bartolomé, Red de Salud San Juan de Lurigancho y ESSALUD, y con el apoyo de la Organización Panamericana de Salud y la Universidad McMaster de Canadá, elaboró una Guía de Práctica Clínica para la prevención y manejo de la preeclampsia, con el objetivo de estandarizar los criterios clínicos basados en evidencia científica disponible siguiendo la metodología AGREE II y Grade $^{5}$.

La guía brinda 16 recomendaciones para la prevención y tratamiento de la preeclampsia, dentro de las cuales destacan el uso de sulfato de magnesio en pacientes con preeclampsia con criterios de severidad es decir aquellas que presentan una presión arterial sistólica $\geq 160 \mathrm{~mm}$ de $\mathrm{Hg}$ o una presión arterial diastólica $\geq 110 \mathrm{~mm} \mathrm{Hg}$, o la presencia de trombocitopenia $<100,000 \times 10^{9} / \mathrm{L}$, o el incremento de las enzimas hepáticas, o el aumento de la creatinina $>1,1 \mathrm{mg} / \mathrm{dl}$, o la presencia de trastornos cerebrales o visuales, o la presencia de edema pulmonar o cianosis, o la presencia de una insuficiencia renal progresiva. También se dan recomendaciones para la culminación del embarazo en la preeclampsia con criterios de severidad en aquellas gestaciones menores de 24 semanas o mayores de 33 semanas. Entre las 24 y 33 semanas de gestación se recomienda un manejo expectante siempre que no haya daño de órgano blanco y se pueda realizar un control estricto del estado de salud materno y fetal.

Finalmente para la prevención de la preeclampsia, en aquellas gestantes con riesgo de desarrollar preeclampsia se recomienda usar el ácido acetilsalicílico desde antes de las 16 semanas y hasta las 34 semanas de gestación.

Con la publicación de esta guía se espera que el Instituto Nacional Materno Perinatal haya contribuido a la mejora de la calidad de atención de las pacientes con trastornos hipertensivos del embarazo y de esta manera haya contribuido a la disminución de la morbilidad y mortalidad materna perinatal asociada a esta complicación del embarazo.

\footnotetext{
1 Instituto Nacional Materno Perinatal. Lima, Perú.

a Médico Ginecólogo-Obstetra. Director del Instituto Nacional Materno Perinatal. Coordinador de Asistencia Técnica del Instituto de Salud Popular. Consultor de Pathfinder International. Docente de la Universidad Nacional Mayor de San Marcos Lima-Perú.

Citar como:Citar como: Guevara R. Preeclampsia, problema de salud pública. Rev Peru Investig Matern Perinat 2019; 8(2):7-8. DOI: https://doi.org/10.33421/inmp.2019147
} 


\section{REFERENCIAS BIBLIOGRÁFICAS}

1. American College of Obstetricians and Gynecologists. Gestational Hypertension and Preeclampsia. ACOG Practice Bulletins. Vol. 133 N¹ January 2019. Pags. E1 - E25.

2. Banco Mundial. Infografía: Salvar vidas maternas, 6 mayo 2014. https://www.Bancomundial.org/es/news / feature/2014/05/06/infographic-saving-mothers-lives.

3. Centro Nacional de Epidemiología, Prevención y Control de Enfermedades del Ministerio de Salud. Boletín Epidemiológico del Perú. Vol 27 - SE 26. 2019. ISSN 2415- 0762.

4. Oficina de Epidemiología y Saneamiento Ambiental del Instituto Nacional Materno Perinatal. 2019.

5. Instituto Nacional Materno Perinatal. Guía de Práctica Clínica para la prevención y manejo de la Preeclampsia y Eclampsia. $1^{a}$ Edición. Marzo 2018. ISBN: 978-612-47674-1-8.

\section{PREECLAMPSIA, PUBLIC HEALTH PROBLEM}

Preclampsia is a pregnancy disorder associated with the onset of hypertension after 20 weeks, with or without proteinuria, and with the presence or not, of a wide variety of symptoms such as pain in the upper right quadrant of the abdomen, headache ${ }^{1}$. It is an irreversible disease that affects multiple organs and, because it injures the mother and the fetus, is responsible for a considerable proportion of maternal and perinatal deaths.

According to the World Health Organization, preeclampsia is the second leading cause of death in the world with $14 \%$; and in Peru in the I semester of 2018 it was the first cause of maternal death with $28,7 \%{ }^{3}$.

In the National Maternal Perinatal Institute between 2007 and 2018 there were 97 cases of maternal death, and preeclampsia was the first cause with $44,3 \% 4$. Also between 2012 and 2018, a total of 1870 cases of extreme maternal morbidity were treated in the institute, the main cause being hypertensive disorders of pregnancy with $56,6 \%$ (164 cases) between preeclampsia with criteria of severity, HELLP syndrome and eclampsia ${ }^{4}$.

Therefore, preeclampsia, being a problem of great magnitude and a great social impact, should be considered as a public health problem. For this reason, between 2016 and 2017, the National Maternal Perinatal Institute, together with the National Institute of Health, San Bartolomé Hospital, San Juan de Lurigancho Health Network and ESSALUD, and with the support of the Pan American Health Organization and the McMaster University of Canada, developed a Clinical Practice Guide for the prevention and management of preeclampsia, with the objective of standardizing the clinical criteria based on available scientific evidence following the AGREE II and Grade methodology 5 .
The guide provides 16 recommendations for the prevention and treatment of preeclampsia, which include the use of magnesium sulfate in patients with preeclampsia with severity criteria, that is, those with systolic blood pressure $\geq 160 \mathrm{mmHg}$ or a diastolic blood pressure $\geq 110 \mathrm{~mm} \mathrm{Hg}$, or the presence of thrombocytopenia $<100,000 \times 109 / \mathrm{L}$, or an increase in liver enzymes, or an increase in creatinine $>1,1$ $\mathrm{mg} / \mathrm{dl}$, or the presence of brain or visual disorders, or the presence of pulmonary edema or cyanosis, or the presence of progressive renal failure. Recommendations are also given for the culmination of pregnancy in preeclampsia with criteria of severity in those gestations under 24 weeks or over 33 weeks. Between 24 and 33 weeks of gestation, expectant management is recommended as long as there is no white organ damage and strict control of maternal and fetal health can be performed.

Finally, for the prevention of preeclampsia, in those pregnant women at risk of developing preeclampsia it is recommended to use acetylsalicylic acid from before 16 weeks and until 34 weeks of gestation.

With the publication of this guide, it is expected that the National Maternal Perinatal Institute has contributed to the improvement of the quality of care of patients with hypertensive disorders of pregnancy and thus contributed to the decrease in perinatal maternal morbidity and mortality associated with this pregnancy complication.

\section{BIBLIOGRAPHIC REFERENCES}

1. American College of Obstetricians and Gynecologists. Gestational Hypertension and Preeclampsia. ACOG Practice Bulletins. Vol. 133 N¹ January 2019. Pags. E1 - E25.

2. Banco Mundial. Infografía: Salvar vidas maternas, 6 mayo 2014. https://www.Bancomundial.org/es/news / feature/2014/05/06/infographic-saving-mothers-lives.

3. Ministerio de Salud. Centro Nacional de Epidemiología, Prevención y Control de Enfermedades. Boletín Epidemiológico del Perú. Vol 27 - SE 26. 2019. ISSN 24150762.

4. Instituto Nacional Materno Perinatal. Oficina de Epidemiología y Salud Ambiental. 2019.

5. Instituto Nacional Materno Perinatal. Guía de Práctica Clínica para la prevención y manejo de la Preeclampsia y Eclampsia. $1^{a}$ Edición. Marzo 2018. ISBN: 978-612-47674-1-8. 